\title{
Analysis of the poor-quality in building elements: providers' perspectives
}

\author{
AbdulLateef Olanrewaju and Hui Jing Alice Lee \\ Universiti Tunku Abdul Rahman (UTAR), Kampar, Malaysia
}

\begin{abstract}
Purpose - Poor quality in building projects is high and increasing. Poor quality can increase the cost of a building by up to more than $50 \%$ and can delay a project by up to $50 \%$. This research investigated the poor quality of building elements/components.

Design/methodology/approach - The site operatives were requested to rate the frequency of poor quality in 25 building elements/components. The frequencies of the poor quality were scored on a five-point Likert scale, ranging from least often to extremely often. The survey forms were administered to construction site operatives by hand delivery.

Findings - The data revealed that poor quality occurred in more than $80 \%$ of the building projects completed. Approximately $40 \%$ of the cost of a building project is attributed to poor quality. In total, $70 \%$ of the respondents measured the poor quality of building elements as being high and frequent. The size and frequency of poor quality are higher in concrete, plaster, brick, foundations and roof trusses.

Practical implications - The research findings would help to reduce claims, disputes, maintenance costs and waste on sites.

Originality/value - This research provides fresh information on poor quality in building projects and provides a systemic process for anticipating poor quality in building projects. The findings also provide an option to increase maintenance span and a means to reduce claims and disputes in the construction sector.
\end{abstract}

Keywords Rework, Contractors, Maintenance-span, Building performance, Site operatives

Paper type Research paper

\section{Introduction}

The construction sector is an economic investment, and its relationship with national development and growth is well-established. The construction sector contributes up to $10 \%$ of the gross domestic product (GDP) and employs more than 10\% of the workforce in many economies (United Nations Economic Commission for Europe, 2021). It has been argued that a vibrant construction sector is required for a country to experience meaningful and long-term development. The construction sector, on the other hand, is underperforming. Projects are completed late, over budget and with low quality standards (Olanrewaju and Abdul-Aziz, 2015). In particular, the finished product's quality is low when compared to other industries. For instance, the cost of poor quality is more than the combined profits of the construction companies in the sector. It is estimated that better quality management could save the UK construction industry up to £12bn a year (Montague, 2018). Similarly, the construction industry of the United States expended $\$ 1,502 \mathrm{bn}$ in 2004 on total construction costs and \$75bn was wasted on rework costs (Bureau of Economic Analysis, 2006). The estimated direct poor quality cost was $21 \%$ in Turkey (Kazaz et al., 2005), $8 \%$ in Uganda (Kakitahi et al., 2014), 9.4\% in Sweden (Josephson and Hammarlund, 1999), 4\% in Australia (Mills et al., 2009)

(C) AbdulLateef Olanrewaju and Hui Jing Alice Lee. Published in Frontiers in Engineering and Built Environment. Published by Emerald Publishing Limited. This article is published under the Creative Commons Attribution (CC BY 4.0) licence. Anyone may reproduce, distribute, translate and create derivative works of this article (for both commercial and non-commercial purposes), subject to full attribution to the original publication and authors. The full terms of this licence may be seen at http:// creativecommons.org/licences/by/4.0/legalcode.
Poor quality of building elements

Received 17 October 2021 Revised 6 December 2021 Accepted 5 February 2022

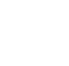

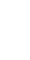


FEBE

2,2

and 5.8\% in the UK (Hall and Tomkins, 2001). However, research has shown that the indirect cost of rework is about ten times the non-quality (Rosenfeld, 2009). Poor quality work in a new building can be due to various factors. The causes have been classified differently, most in terms of design and construction-related factors (Palaneeswaran, 2006; Arditi and Gunaydin, 1998; Shohet and Ciabocco, 2016; Rahimi et al., 2017). Many studies found that design-related factors were the main factors contributing to poor quality. However, since more than $90 \%$ of the cost and time of project delivery is used at the construction level, it is conceivable that the activities at the construction sites have a significant impact on the quality of buildings. In fact, many studies in the USA (Arditi and Gunaydin, 1998), Israel (Shohet and Ciabocco, 2016), Australia (Love and Sing, 2013) and other places suggest that the activities and decisions that take place during construction can significantly mar or improve the quality of the completed buildings.

Although representative data on poor quality work on sites are lacking in Malaysia, the growing concern with the subject is increasing unabated (Plebankiewicz and Malara, 2020; Hassan et al., 2019; Olanrewaju et al., 2011; Islam et al., 2021; Olanrewaju and Lee, 2022). To reduce poor quality in buildings, Construction Industry Development Board Malaysia (CIDB) has developed various quality standards (Abdul-Rahman et al., 1999; Al-Tmeemy et al., 2012; Olanrewaju et al., 2021a). However, fewer studies have been conducted on the causes of the poor quality in buildings (Ahzahar et al., 2011; Yap et al., 2017). Unfortunately, there is a lack of substantial research that has examined quality at the construction operational level. Importantly, there is no research that examines the extent of the defects in the building elements or components. Therefore, to prevent and control poor quality buildings, a major task is to examine the extent of the occurrence of poor quality in the building elements in order to develop an effective construction management framework capable of reducing poor quality in buildings.

\section{Literature review and theoretical framework}

The quality of a building has profound impacts on the building's performance, users and community. The quality of building projects is determined by a variety of factors, including procurement method, construction methods, materials, design and construction team competencies, climatic factors and client type.

\subsection{Poor quality, defects, rework and maintenance}

There is no consensus on the definition of "poor quality" in buildings. Defects, rework, poor quality, snagging, non-quality, deviation and noncompliance have all been used interchangeably to denote poor quality. In this article, all the items are synonymous with poor quality. Juran (1999) defined quality as "fitness for purpose". Quality implies providing customer satisfaction and meeting the required standards (CIOB, 2019). It is also defined as meeting the requirements of the customer; lack of defects; lack of rework; completion on time and within budget. Quality means zero defects, delivery within budget and time stripped out of waste (Latham, 1994). Defects hinder the functional performance of the buildings and services. Defects influence the occupants'/clients' satisfaction and lead to disputes and litigation amongst clients/users, developers and maintenance organisations (Lee et al., 2018; Zalejska-Jonsson and Gunnelin, 2019; Olanrewaju and Lee, 2022). Poor quality can manifest within a structure, fabric, services and other facilities. Defects that occur during any of the design and construction phases will reduce the maintenance span of the building. The maintenance span is the period between one repair and the next or previous repairs. Systemic maintenance management framework, as Olanrewaju (Olanrewaju et al., 2021b) explained, aims in increasing the maintenance span of the buildings. A shorter maintenance span will reduce building availability, building performance and increase maintenance costs. 
The quality of a building can be affected during any of the building design processes. However, most of the poor quality problems are instigated or heightened during the construction phase of the projects. Many design-induced quality problems can be reduced or corrected during the construction phase. Many big and medium-sized construction companies have in-housed "quality management" or a quality assurance/quality control department or unit dedicated to the control of the quality of projects. The department is strategic to the survival of the companies. However, despite the various measures to increase the quality of building projects, the rates of poor quality are dominant in the global construction sectors. For example, Palaneeswaran's (2006) study showed that the poor quality cost in Hong Kong could range between 5 and $20 \%$ of the original contract value. Research shows that rework originates from design and construction factors. In Iran, Heravi and Jafari (2014) noted that the optimum level of poor quality cost was $7.4 \%$ of the total project cost. In Nigeria, the poor-quality cost was $4.5 \%$ of the cost of the project (Oyewobi and Ogunsemi, 2010). Although the research did not discuss the causes of rework, it indicated that the causes of rework varied among countries and were related to design and construction activities. Empirical data from a South African study also revealed that the cost of rework to the original contract value was 5.12\% (Simpeh et al., 2015). Empirical data involving contractors, consultants, quantity surveying firms and architecture firms revealed that rework accounted for $24.94 \%$ of the construction schedule growth in Singapore (Hwang and Yang, 2014). In Sweden, Josephson and Hammarlund (1999) estimated that the cost of rework in building projects ranged from 2 to $4 \%$. The research found that the cost of correcting a quality failure was about $6 \%$ of the production cost and delayed projects by up to $11 \%$. According to the research, reworks were caused by design factors, site management, errors, omissions, procurement types and weather. A study conducted in Malaysia showed that the cost of non-conformance on construction sites was between 5 and $6 \%$ of the total project cost, according to Abdul-Rahman et al. (1996). A recent study in Malaysia by Yap et al. (2017) also arrived at a similar value of between 3.1 and $6.0 \%$ of the project value. Recent research in Portugal showed that the cost of rework could be up to $7 \%$ of the contract sum (dos Reis Almeida, 2011). Research has shown that the cost of quality in Dubai is 1.3\% (Abdelsalam and Gad, 2009).

From the foregoing, considering the impacts of poor quality on building performance, contractors, clients, developers and users, the logical question requiring an answer is "What are the determinants of poor quality in buildings?" Knowledge of the determinants will allow organisations to reduce rework and improve project performance, profits and satisfaction. For this reason, multiple studies have investigated the determinants of poor quality in buildings (Love et al., 2005; Palaneeswaran, 2006; Carey, 2010; Simpeh et al., 2015; Olanrewaju and Lee, 2022; CIOB, 2019). However, a major area of quality management in the building delivery process that is consistently neglected in research is the extent of defects in building elements. Examining the determinants alone is not sufficient. Examining the extent of the occurrence of poor quality in building elements requires adopting a problem-seeking approach to enable the deployment of measures and techniques to solve the problems associated with poor quality and maintenance. It is biological to examine the possibility that poor quality will occur in the different building elements for the planning of resources. The biological argument or basis for this reasoning cannot be disproved. It is natural, that by knowing which building elements have a higher occurrence of poor quality in advance, the major determinants can be examined and the possible measures and consequences can be examined accordingly (Olanrewaju and Lee, 2022). For instance, by knowing the extent of poor quality in a concrete beam, the degree of poor quality in associated/adjoining elements like ceilings, windows, doors, or partitions, and the building elements underneath the beam can be assessed. Earlier research studies have provided evidence of the determinants of poor 
FEBE

2,2

quality in buildings, but scanty work has sought to quantify the extent of poor quality in the building elements. According to Love and Sing (2013), there is a need to investigate the likelihood of rework in a building in order to provide an effective risk management framework for building projects. Like previous studies that focused on particular elements or the whole construction selector, Simpeh et al. (2015) developed a rework probability model for construction projects to know the likelihood of a rework occurring in South Africa. Therefore, this research determined the extent of the occurrence of poor quality in the various building elements/components in Malaysia.

\section{Research methodology and analytical techniques}

This research used a literature review and a survey questionnaire to achieve its aim. Primary data were collected through survey questionnaires. The respondents were selected based on convenience sampling. As Olanrewaju and Idrus (2020) explained, convenience sampling is appropriate for research with a limited timeframe and cost. In total, 25 building elements were derived from literature (Plebankiewicz and Malara, 2020; Hassan et al., 2019; Loves and Sing, 2013; Simpe et al., 2015; Islam et al., 2021; Olanrewaju and Lee, 2022), and discussion was conducted with staff of contracting organisations. The questionnaire went through two pilot surveys that were comprised of construction operatives. The questionnaires were administered by hand to the construction site workers. The surveys were administered on the building sites between 26 and 27 June 2019 and 4 and 8 July 2019. The respondents were questioned about the rate of occurrence of poor quality in building elements. The occurrence of poor quality in the elements was measured on a five-point Likert scale, where $1=$ least often, $2=$ less often, $3=$ often, $4=$ very often, and $5=$ extremely often. The extent of the poor quality was estimated by the average frequency index (AFI) (Equation 1) and the standard deviation.

$$
A F I=\frac{\sum_{i=0} a_{i} x_{i}}{5 \sum_{i=0}^{5} x_{i}} \times 100
$$

where $a_{i}$ was the index of a group, constant expressing the weight given to the group; $x_{i}$ was the frequency of the responses, $i=1,2,3,4$ and 5 , and was described as below: $x_{1}, x_{2}, x_{3}, x_{4}, x_{5}, x_{6}$ were the frequencies of the responses corresponding to $a_{1}=1$, $a_{2}=2, a_{3}=3, a_{4}=4, a_{5}=5$, respectively. For interpretation, an AFI score of 1.00-20.00 denoted least often, 21.00-40.00 denoted less often, 41.00-60.00 denoted often, 61.00-80.00 denoted very often, and 81.00-100.00 denoted extremely often. Thus, the element with the highest AFI score is also the element with the lowest quality standard. There was a pooled difference of $1.0 \%$ between each of the scales. The analyses involved descriptive and diagnostic analyses. The computed statistical tests were the one-way test, AFI, reliability tests, mode and standard deviation. For data analytics, all collected data were analysed using IBM SPSS 25. The $t$-test was conducted to examine whether poor quality occurred in each of the elements or not.

\section{Results of data collection}

A total of 284 forms were administered. However, 106 responses were received, representing a $37 \%$ response rate. The findings are presented and discussed in the sections that follow.

\subsection{Analysing the respondents' profiles}

Tables 1 and 2 and Figure 1 contain and depict the results of the respondents' profiles. The data revealed that more than $43 \%$ of the respondents had bachelor's degrees and $46 \%$ had 
obtained diplomas and SPM/STPM (Table 1). Most of those with BSc degrees were site quantity surveyors, and many were site engineers or site supervisors. About $50 \%$ of those with diplomas were site supervisors, and more than $45 \%$ of the respondents with SPM/STPM were site supervisors. Close to $70 \%$ of the respondents worked with main contractors, whilst the remainder worked with subcontracting organisations (Table 2), and $40 \%$ of the respondents' organisations had completed more than 6 projects in the last five years. To draw insight from the data, it was obvious that the respondents had adequate knowledge and competency to provide unbiased and valid information on the quality standards of buildings.

Poor quality of building elements was not surprising because most construction projects were executed by subcontractors, as most main contractors know how to use construction management and contracting management strategies.

\begin{tabular}{lcccccrr}
\hline Current position & \multicolumn{7}{c}{ Academic background } \\
Site engineer & PMR & SPM/STPM & Diploma & Bachelor degree & Master & Total & \\
Site supervisor & 0 & 0 & 2 & 14 & 1 & 17 & \\
Safe and health officer & 0 & 4 & 12 & 9 & 0 & 25 & \\
Site quantity surveyor & 0 & 0 & 3 & 2 & 0 & 5 & Table 1. \\
Quality officer & 0 & 1 & 2 & 15 & 0 & 17 & 6 \\
Construction manager & 0 & 0 & 1 & 3 & 1 & 4 & Cross-tabulation \\
Site worker/labourer & 8 & 21 & 2 & 2 & 1 & between current \\
Total & 8 & 26 & 23 & 46 & 3 & 106 & position and academic \\
background \\
\hline
\end{tabular}

\begin{tabular}{lcccr}
\hline & & \multicolumn{2}{c}{ Number of project completed } \\
Type of organisation & $0-5$ & $6-10$ & $11-15$ & Total \\
\hline Main contractor & 49 & 19 & 5 & 73 \\
Subcontractor & 17 & 15 & 1 & 33 \\
Total & 66 & 34 & 6 & 106
\end{tabular}

Table 2 . Cross-tabulation between type of organisation and number of projects completed

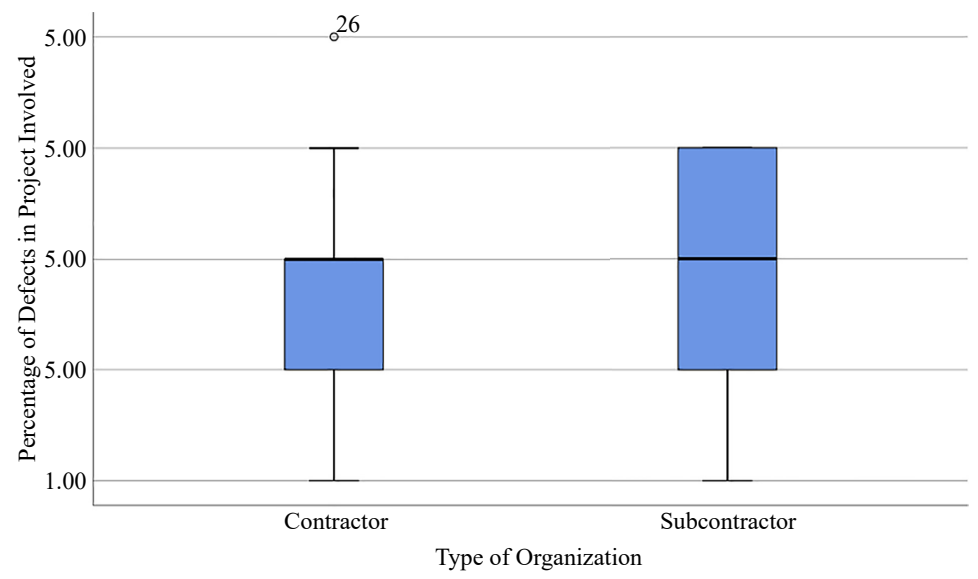

Figure 1.

Boxplot for type of organisation against the percentage of poor quality project 
FEBE

2,2

86

The data revealed that $50 \%$ of the respondents' organisations are involved in the construction of residential buildings and $37 \%$ in the construction of commercial buildings. The remainder is in industrial or other types of buildings. All the completed building projects had poor quality. See Table 3. The mean and standard deviation of the poor quality in the buildings are 50 and $10 \%$. In other words, the minimum level of poor quality or rework in a building is $40 \%$. In terms of cost, $40 \%$ of the cost of a building project is attributed to poor quality. By extension about $40 \%$ of the delays in a building project can be explained by reworks during construction. The data also revealed that, about $80 \%$ of the construction work had major poor-quality problems. As Table 4 reveals the higher the number of projects executed, the higher the number of poor quality in the projects. A plausible implication of this is that the contractors are sacrificing time and cost for quality work. The pressure may come from the clients or the contractors, or both. Due to the increasing demand for clients' earlier completion times, lower costs that are affecting the profit margins of construction companies are forcing contractors to deliver poor quality buildings.

\subsection{Analysing the hierarchy of the building elements with occurrences of poor quality}

The result of the Cronbach's alpha for all the 25 elements was 0.793 (Table 5). The validity of the elements ranged from 0.557 to 0.863 . The results of the one-way $t$-test revealed that the data were generally statistically significant (Table 6). The small standard errors were approximately equal to zero. Kaiser's measure of sampling adequacy was statistically significant $\left.\chi^{2}(300)=1961.282, p<0.001, N=0.818\right)$. The results signified a lack of

\begin{tabular}{lcr}
\hline Percentage & Frequency & Percent \\
\hline $0-20 \%$ & 7 & 6.6 \\
$21-40 \%$ & 38 & 35.8 \\
$41-60 \%$ & 39 & 36.8 \\
$61-80 \%$ & 21 & 19.8 \\
$81-100 \%$ & 1 & 0.9 \\
Total & 106 & 100.0 \\
\hline
\end{tabular}

Table 3.

Percentage of projects with poor quality

\begin{tabular}{llc}
\hline & Percentage of defects in project \\
\hline Number of projects completed & Correlation coefficient & $0.329 * *$ \\
& Sig. (2-tailed) & 0.001 \\
& $N$ & 106 \\
Note(s): $* *$ Correlation is significant at the 0.01 level (2-tailed) & \\
\hline
\end{tabular}

Table 4.

Correlations

Spearman's rho

Note(s): **Correlation is significant at the 0.01 level (2-tailed)

\begin{tabular}{lllc}
\hline Cronbach's Alpha & \multirow{2}{*}{ Part 1 } & Value & 0.753 \\
& & No of items & 13 \\
& Part 2 & Value & 0.764 \\
& & No of items & 12 \\
Correlation between forms & Total no of items & & 25 \\
Spearman-Brown coefficient & Equal length & & 0.658 \\
Guttman split-half coefficient & Unequal length & & 0.794 \\
& & & 0.794 \\
& & & 0.793
\end{tabular}

Table 5.

Reliability statistics

Guttman split-half coefficient 


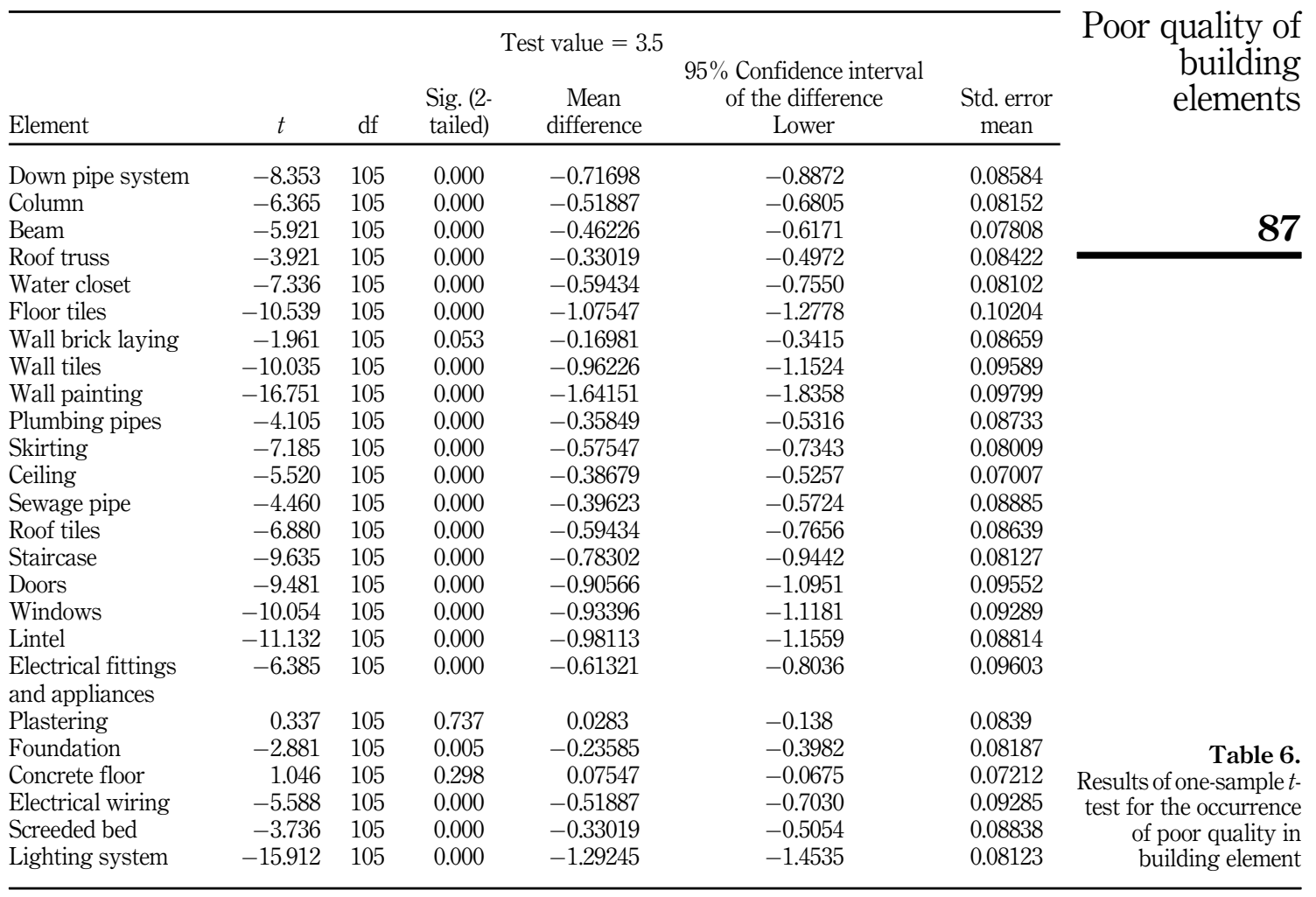

multicollinearity amongst the elements. The results also returned a statistical determinant of 1.294E-9. Collectively, the interpretation of these statistics is that the survey results are indicative of the construction sector generally and that poor quality is endemic in buildings. The descriptive statistics on the hierarchy of the elements are contained in Table 7 . The survey found that more than $37 \%$ of the respondents measured that poor quality was very or extremely often in the building elements. A total of $38 \%$ of the measurements indicated that there were occurrences of poor quality in the elements of the building. Only $4 \%$ of respondents reported that poor quality occurred the least frequently in the elements. The cumulative AFI score for the occurrence of poor quality in all the elements was $57.78 \%$, whilst the cumulative standard deviation (SD) was $17.79 \%$. The AFI for the occurrence of poor quality in the buildings fell between 37.17 and $71.51 \%$. The AFI for 15 elements was higher than average for the occurrence of poor quality in the buildings. Based on the index in Section 3 , the rate of occurrence of poor quality in the 25 elements was very high. The data revealed that poor quality was not often found in wall painting.

\section{Discussion of the occurrences of poor quality in building elements}

Due to space constraints, only the first 15 elements with AFI values greater than the composite AFI were explained further. The data revealed that poor quality was prevalent in $80 \%$ of the measured elements. Poor quality concrete floors were higher as compared to other elements. This is not surprising because concrete floors are one of the major building 


\begin{tabular}{|c|c|c|c|c|c|c|c|c|}
\hline $\begin{array}{l}\text { FEBE } \\
2,2\end{array}$ & Element & Least & Less & Often & $\begin{array}{l}\text { Very } \\
\text { often }\end{array}$ & $\begin{array}{l}\text { Extremely } \\
\text { often }\end{array}$ & $\begin{array}{l}\text { Standard } \\
\text { deviation }\end{array}$ & AFI \\
\hline \multirow{20}{*}{88} & Concrete floor & 0 & 6 & 43 & 47 & 10 & 14.851 & 71.509 \\
\hline & Plastering & 1 & 12 & 34 & 48 & 11 & 17.284 & 70.566 \\
\hline & Wall/brick laying & 1 & 19 & 38 & 4 & 8 & 17.829 & 66.604 \\
\hline & Foundation & 0 & 21 & 42 & 37 & 6 & 16.858 & 65.283 \\
\hline & Roof truss & 1 & 23 & 45 & 31 & 6 & 17.342 & 63.396 \\
\hline & Screed bed & 2 & 25 & 37 & 37 & 5 & 18.199 & 63.396 \\
\hline & Plumbing pipes & 4 & 20 & 43 & 35 & 4 & 17.982 & 62.830 \\
\hline & Ceiling & 2 & 14 & 62 & 26 & 2 & 14.428 & 62.264 \\
\hline & Sewage pipes & 3 & 25 & 41 & 32 & 5 & 18.295 & 62.075 \\
\hline & Beam & 2 & 24 & 50 & 28 & 2 & 16.077 & 60.755 \\
\hline & Column & 8 & 29 & 49 & 18 & 2 & 16.786 & 59.623 \\
\hline & Electrical wiring & 3 & 34 & 37 & 26 & 6 & 19.120 & 59.623 \\
\hline & Skirting & 5 & 23 & 55 & 21 & 2 & 16.492 & 58.491 \\
\hline & Water closet & 3 & 31 & 47 & 23 & 2 & 16.683 & 58.113 \\
\hline & Roof tiles & 3 & 34 & 43 & 22 & 4 & 17.788 & 58.113 \\
\hline & $\begin{array}{l}\text { Electrical fitting and } \\
\text { appliances }\end{array}$ & 5 & 37 & 35 & 23 & 6 & 19.774 & 57.736 \\
\hline & Down pipe systems & 2 & 46 & 43 & 13 & 2 & 17.675 & 55.660 \\
\hline & Staircase & 5 & 39 & 45 & 15 & 2 & 16.734 & 54.340 \\
\hline & Doors & 9 & 49 & 29 & 14 & 5 & 19.669 & 51.887 \\
\hline & Windows & 9 & 49 & 32 & 11 & 5 & 19.127 & 51.321 \\
\hline \multirow{5}{*}{$\begin{array}{l}\text { Table } 7 \text {. } \\
\text { Descriptive statistics } \\
\text { for the occurrence of } \\
\text { poor quality in building } \\
\text { element }\end{array}$} & Wall tiles & 13 & 44 & 32 & 13 & 4 & 19.746 & 50.755 \\
\hline & Lintel & 8 & 52 & 34 & 7 & 5 & 18.149 & 50.377 \\
\hline & Floor tiles & 20 & 41 & 30 & 10 & 5 & 21.012 & 48.491 \\
\hline & Lighting system & 19 & 53 & 29 & 3 & 2 & 16.726 & 44.151 \\
\hline & Wall painting & 48 & 37 & 11 & 8 & 2 & 20.178 & 37.170 \\
\hline
\end{tabular}

elements with a consistent high of rework (Tang et al., 2004) and that concrete frame structures have the worst conformance to quality standards (Heravi and Jafari, 2014). The primary purpose of the concrete floor is to be suitable for the intended purpose and have adequate stiffness to support the tiles and adhesive or other coverings (CIOB, 2019). The floor needs to be even, otherwise, it will require more finishing materials. Many buildings under construction have collapsed due to poor concrete floors in Malaysia (The Star Online, 2017; Borneo Post Online, 2015). As precast concrete is delivered to the sites, there is very little time to correct unsatisfactory conditions as workers are placing the concrete, and the concrete will harden quickly (Fisk and Rapp, 2004). Therefore, site supervision must ensure that the grade of the concrete adheres to the required standards. Excavation, formwork and reinforcement must be adequately inspected. Apart from the poor quality of materials, many concrete floors are not properly cured to gain enough strength before work is started on top of them and formworks are prematurely removed.

The data also revealed that reworks are also common with plastering works. Poor plasters were identified as prevalent in the buildings. Some examples of common poor plasters include blistering of the plastered surface, plaster debonding, cracks on the plastered surface, efflorescence and loose plaster. The most common problem with plastering is that the plaster at the edges of the walls, ceiling, openings, doors and skirting is not smooth and even. Hong (2016) found that building contractors identified that rendering and plastering cracks in the ceilings are common during the defect liability periods in Malaysia. Surface cracks and hairline cracks were obvious in many new buildings. The poor plaster is evidence of poor workmanship and materials. Plants and equipment also have a major contribution to poor 
quality in the plastering work in the buildings. For instance, often a suitable scaffold is not used. Poor supervision has also been cited as a major cause of poor quality in plastering work.

Bricklaying requires great skills. As a result, site workers' pay little attention to the brickwork's construction. In fact, once the frames are in place, laying brick is sort of a "filling the space" exercise, as commented by some site operatives. Brick is expected to properly align with the frame structures and be able to support the plastering. Inappropriate or disproportionate mortar and wrong alignment are some of the major problems leading to poor quality in brickwall construction. Although the bricks may be manufactured to the required standards, poor bedding and jointing contribute to the poor quality of the brick walls. Poor monitoring and supervision were also cited as major causes of poor brick walls in the buildings. Due to the poor condition and performance of concrete floors being rated by the respondents, it is not surprising that poor quality is common in foundations. The structural stability of buildings depends upon the foundation of the building. In Malaysia, walls are designed/constructed to carry a load. Hence, floors, foundations, columns and beams are designed as framed structures. However, the major problems with the foundation failure and settlements are due to poor workmanship and poor site investigations. The data also revealed that poor quality or reworked roofing carcassing is common. Poor quality roofing is usually due to poor workmanship and the use of substandard materials. The major problem is with the laying of the roofing tiles. Also, the roof trusses are not usually strong enough to support the tiles. In effect, this has increased the rate of complaints during the defect liability period, especially, during the heavy rainy season. The quality of the screed bed is associated with the quality of the concrete floor and the quality of the materials and labour for the screed bed. Defects in the screed bed during the defect liability periods were also reported by Hong (2016).

Temperature affects concrete and bricks. Construction materials adjust more differently to changes in temperature. The bricks and concrete pressurise the pipes embedded in them. This may damage the pipes. Poor jointing would damage the pipes. The data showed that the respondents measured that poor quality that has led to rework has been very common in plumbing pipes in the buildings. The reason is that the plumbing materials were selected without due consideration of the wall and floor materials that supported/concealed the pipes (Olanrewaju et al., 2021c). The materials may also corrode rapidly if suitable materials are not selected. Many of the plumbing problems were identified during the pre-commissioning phase of the buildings. However, in a number of cases, they are not corrected properly. As the data revealed, most of the ceilings are also defective. More than $90 \%$ of the respondents measured poor quality ceilings is rampant. Defective ceilings are associated with roofing carcassing, roofing sheets/tiles and finishes. Defective roofing often damages ceilings especially during the rainy season. Although, winter weather may not damage the roof, freezing rain would damage the roof and exposed ceilings. In particular, ice may build up in the gutter and prevent water from draining properly from the roof. But while, winter weather is not common in Malaysia, the rainfall is heavy and prevalent. Many of the exposed roofs also provide passage for rodents, which often damage ceilings and enter the buildings. Hence, problems associated with roofing often manifest after the defect liability (Olanrewaju et al., 2021c).

Poor quality sewage pipes during the defect liability period are high. Sewer pipes collect and dispose of wastewater, urine and excrement from buildings into sewers. Most of the pipes are made from plastic or metal. Often, the pipes may be damaged due to improper laying or due to the weight of the material placed on them during construction. Pipes should be properly investigated before and after backfilling. Fisk and Rapp (2004) recommended that pipes be inspected during the final phases to identify the pipes that require cleaning before commissioning. Poor workmanship causes most of the rework in sewage work. In fact, many of the occurrences of rework are due to slop that often prevents the waste from draining smoothly due to blockage. Many of the problems are detected during the inspection and 
FEBE

2,2

90 commissioning period. However, most are only known during the defect liability period. Backing should be properly done because it can exert more pressure on the piping or break the pipes.

There are a lot of media reports on the collapse of a beam, slab or column in buildings due to poor curing and inferior materials in Malaysia (The Star Online, 2017, 2019a, b; NST Business, 2019; NST, 2019; Borneo Post Online, 2015). The defects in the beams and columns also affect the building elements/components beneath them. For instance, Yatim and Zakaria's (2008) research revealed that occupants of new buildings in Malaysia were generally disappointed with the misalignments in the doors and window frames. The gaps might also include those between the lintels and door and window frames. The reasons for these include poor curing, inadequate vibration and unsuitable materials. Another reason noted during the site visits for the poor quality was the load placed on the members that exceeded what they could carry. The preliminary results of the recent collapse of 21 storey building in Lagos, Nigeria, that killed more than 40 site operatives and visitors revealed that it was due to excessive load and poor curing of the concrete frames. On many occasions, in order to speed up the construction progress, work is started before the beam and columns gain the required maximum strength. Therefore, the site supervisory personnel must ensure that the beams and columns are correctly graded and must review and obtain copies of the certified materials from the batch to ensure that the materials meet the concrete performance characteristics. According to Fisk and Rapp (2004), loads from nearby vibrating equipment should be avoided, and backfilling should be delayed after the stripping of the formwork to allow the concrete to gain sufficient strength.

Poor quality skirtings also occurred very often, as the data revealed. Skirtings are run around the edges of rooms to prevent people, furniture, etc. from kicking/hitting the base of the walls. Skirting serves as protection between walls and floors. Skirting is also made for decorative purposes and is used to conceal electrical wiring. They are usually made from tiles and timber. Vinyl, aluminium and uPVC are also common but not very popular in residential buildings. A common problem with the skirting is the quality of the materials, which are not always appropriate. Furthermore, the exposed faces of the skirting are not well-treated and are unattractive. The screed bed and screeded barking are poorly prepared, which often leads to uneven skirting. Uneven skirting sometimes leads to accidents during the occupation as occupants hit their feet against the skirting. This has forced many homebuyers/home users to change their skirts during the defect liability period.

The water closet (WC) is the common method of disposing of human excreta (e.g. faeces and urine) in buildings in Malaysia. The bidet is also very common, but most of the poor quality is found in the WC. The WC is a ceramic sanitary-ware product and is supplied in various sizes and quality. There is no restriction on the type of toilets in buildings in Malaysia. However, the WC is the most popular. Our data revealed that poor quality in the WC is found very often. This finding is in tandem with recent research. For instance, Hong (2016) noted that water leakage in the toilet is very common in buildings during the defect liability period. Similarly, based on a survey conducted on residential buildings by a big developer that had QLASSIC and CONQUAS certifications, many of the respondents were unsatisfied by the poor installations of their plumbing work and services (Yatim and Zakaria, 2008). However, because of poor workmanship, blockages are frequent occurring problem in the sanitary system. Rework to WCs is common during the defect liability period. However, most of the reworks are not properly conducted during construction and during the defect liability period. Effectively, most of the defects extend beyond the defect liability period and quickly become the responsibility of the clients and building users. Poor roof tiles are also common, and the replacement cost is often very high. As a matter of course, more than $90 \%$ of the respondents measured the poor roof tiles high. Poor installation, poor materials, misalignment of roofing materials and missing flashing are major causes of poor roof tiles. 
Lack or inappropriate flashing is a major cause of poor roof tiles. Leakage roof tiles allow water to penetrate into the house through holes, which would eventually ruin the insulation, ceiling, walls and flooring and encourage the growth of mildew and mould.

\section{Research implications and limitations}

This research has contributed to the body of knowledge on the poor quality of building work in Malaysia. Future research should investigate the occurrence of defects on elements based on building typology because building typologies affect rework and work performance. This research has investigated the poor quality of the buildings from the site operation perspective. However, a major limitation of this research is probably the sample size. Therefore, future research could make an attempt to increase the sample size. It would be interesting if future research could also increase the number of elements. Future research should examine the measures to reduce poor quality during the site operation process.

\section{Conclusion and recommendations to site operatives and the construction sector}

The survey involved operatives in the building industry. Studies have examined the poor quality and failures in buildings, yet many poor-quality problems in design, construction and maintenance continue to reduce the functional value of buildings. This research has analysed poor quality in building elements from the providers' perspective. The results of the survey suggest that the sector accepts poor quality as a normal phenomenon. Even though most of the poor works occurred during construction, it was either not rectified correctly or not reworked at all. In tandem with findings from most countries, poor quality in building is high in Malaysia. Poor quality is prevalent in concreting and masonry work, the majority of which is the result of poor workmanship and material quality. The quality management system of construction projects requires scrutiny to improve building performance. Apart from adhering to the CIDB guidelines and standards to improve the quality of workmanship, it is important for the contractors and subcontractors to formulate a procedure to monitor workers and supervisors. The guidelines or standard operating procedures should indicate the levels of supervision and investigation that each of the building elements requires. The material management processes require strengthening. The various quality management systems should be updated, and the operatives could need to attend refresher courses to update their knowledge and skills. The resident engineers, resident architects and the resident construction manager should give clear and decisive instructions and provide adequate and timely responses to contractors' questions and queries. Only qualified personnel should be engaged. However, quality assurance might not be effective if this is not the case. Running a quality management system is not sufficient for delivering quality buildings because the "quality standard" could be wrong, or simply, the workers may not adhere to its implementation.

\section{References}

Abdelsalam, H.M. and Gad, M.M. (2009), "Cost of quality in Dubai: an analytical case study of residential construction projects”, International Journal of Project Management, Vol. 27 No. 5, pp. 501-511.

Abdul-Rahman, H., Kwan, C.L. and Woods, P.C. (1999), "Quality function deployment in construction design: application in low-cost housing design", International Journal of Quality and Reliability Management, Vol. 16 No. 6, pp. 591-605, doi: 10.1108/02656719910268198.

Abdul-Rahman, H., Thompson, P.A. and Whyte, I.L. (1996), "Capturing the cost of non- conformance on construction sites: an application of the quality cost matrix", International Journal of Quality and Reliability Management, Vol. 13 No. 1, pp. 48-60. 
FEBE

2,2

92

Ahzahar, N., et. al. (2011), "A study of contribution factors to building failures and defects in construction industry”, Procedia Engineering, Vol. 20, pp. 249-255.

Al-Tmeemy, S.M.H., Abdul-Rahman, H. and Harun, Z. (2012), "Contractors' perception of the use of costs of quality system in Malaysian building construction projects", International Journal of Project Management, Vol. 30 No. 7, pp. 827-838.

Arditi, D. and Gunaydin, H.M. (1998), "Factors that affect process quality in the life cycle of building projects", Journal of Construction Engineering and Management, Vol. 124 No. 3, pp. 194-203.

Borneo Post Online (2015), "Construction workers escape death in building floor collapse", 13 August, available at: https://www.theborneopost.com/2015/08/13/construction-workers-escape-death-inbuilding- floor-collapse (accessed 12 December 2019).

Bureau of Economic Analysis (BEA) (2006), "Gross domestic product by industry in current dollars", available at: http://bea.gov/bea/dn2/gdpbyind_data.htm (accessed 20 October 2006).

Carey, C. (2010), Avoiding Project Rework: Measure Twice and Cut Once, Blueprint Software Systems, available at: http://www.blueprintsys.com/blog (accessed 12 December 2019).

CIOB (Chartered Institute of Building) (2019), "Code of quality management: guide to best practice construction quality management”, ISBN 978-1-9162063-1-1, available at: www.ciob.org.

dos Reis Almeida, R.A.S. (2011), "Evaluation and modelling of the costs of non-quality in the Portuguese construction industry", available at: https://fenix.tecnico.ulisboa.pt/downloadFile/ 395143180796/abstract.pdf (accessed 12 June 2020).

Fisk, E.R. and Rapp, R.R. (2004), Introduction to Engineering Construction Inspection, John Wiley and Sons, Hoboken, New Jersey.

Hall, M. and Tomkins, C. (2001), "A cost of quality analysis of a building project: towards a complete methodology for design and build", Construction Management and Economics, Vol. 19 No. 7, pp. 727-740.

Hassan, A.K., Adeleke, A.Q. and Taofeeq, D.M. (2019), "The effects of project triple constraint on Malaysia building projects", Social Science and Humanities Journal, Vol. 3 No. 5, pp. 1222-1238.

Heravi, G. and Jafari, A. (2014), "Cost of quality evaluation in mass-housing projects in developing countries", Journal of Construction Engineering and Management, Vol. 140 No. 5, 04014004.

Hong, C.H. (2016), "Investigation of defects in new buildings in Malaysia”, Unpublished BSc., UTAR.

Hwang, B.G. and Yang, S. (2014), "Rework and schedule performance: a profile of incidence, impact, causes and solutions", Engineering, Construction and Architectural Management, Vol. 21 No. 2, pp. 190-205.

Islam, R., Nazifa, T.H., Mohammed, S.F., Zishan, M.A., Yusof, Z.M. and Mong, S.G. (2021), "Impacts of design deficiencies on maintenance cost of high-rise residential buildings and mitigation measures”, Journal of Building Engineering, Vol. 39, 102215.

Josephson, P.E. and Hammarlund, Y. (1999), "The causes and costs of defects in construction: a study of seven building projects", Automation in Construction, Vol. 8 No. 6, pp. 681-687.

Juran, J.M. (1999), Juran's Quality Handbook, Godfrey, A.B. (Ed.), McGraw-Hill, New York, Vol. 5.

Kakitahi, J.M., Alinaitwe, H.M., Landin, A. and Rodrigues, M.J. (2014), “A comparison of construction related rework in Uganda and Mozambique", Journal of Construction Project Management and Innovation, Vol. 4 No. 1, pp. 770-781.

Kazaz, A., Birgonul, M.T. and Ulubeyli, S. (2005), "Cost-based analysis of quality in developing countries: a case study of building projects", Building and Environment, Vol. 40 No. 10, pp. 1356-1365.

Latham, M. (1994), Constructing the Team, HMSO, London.

Lee, S., Lee, S. and Kim, J. (2018), "Evaluating the impact of defect risks in residential buildings at the occupancy phase", Sustainability, Vol. 10 No. 12, p. 4466. 
Love, P.E.D., Edwards, D.J. and Smith, J. (2005), "A forensic examination of the causal mechanisms of rework in a structural steel supply chain”, Managerial Auditing Journal, Vol. 20, pp. 187-197.

Love, P.E.D. and Sing, C. (2013), "Determining the probabilistic distribution of rework costs in construction and engineering projects", Journal of Structure and Infrastructure Engineering, Vol. 9, p. 113.

Mills, A., Love, P.E. and Williams, P. (2009), "Defect costs in residential construction", Journal of Construction Engineering and Management, Vol. 135 No. 1, pp. 12-16.

Montague, A. (2018), “Defects cost more than profits': CIOB launches urgent course on quality”, Global elements Construction Review, 19 September, available at: www.globalconstructionreview.com/news/ defects-cost-more-profits-ciob-launches-urgent-cou (accessed 17 February 2020).

New Straits Times (2019), "Gombak building collapse: CIDB reminds industry to put safety first", 29 May, available at: https://www.nst.com.my/news/nation/2019/05/492380/gombak- buildingcollapse-cidb-reminds-industry-put-safety-first (accessed 13 December 2019).

NST Business (2019), "Eco world confirms incident at Bukit Bintang City Centre project site", 29 January, available at: https:/www.nst.com.my/news/nation/2019/01/455497/eco-worldconfirms-incident-bukit-bintang-city-centre-project-site (accessed 13 December 2019).

Olanrewaju, A., Bong, Z.X. and Preece, C. (2021a), "Establishment of pre-qualification criteria for the selection of subcontractors by the prime constructors for building projects", Journal of Building Engineering, 103644.

Olanrewaju, A.A. and Abdul-Aziz, A. (2015), Building Maintenance Processes and Practices, Springer, Singapore.

Olanrewaju, A., Akbar, A.R.N., Azmi, N.A. and Hong, T.R. (2021b), "Procurement of maintenance management for public high rise residential buildings", Environment-Behaviour Proceedings Journal, Vol. 6 No. 17, pp. 235-240.

Olanrewaju, A., Tan, Y.Y. and Soh, S.N. (2021c), "Defect characterisations in the Malaysian affordable housing", International Journal of Building Pathology and Adaptation, Vol. ahead-of-print No. ahead-of-print, doi: 10.1108/IJBPA-11-2018-0095.

Olanrewaju, A.A., Khamidi, M.F. and Idrus, A. (2011), "Appraisal of the building maintenance management practices of Malaysian universities", Journal of Building Appraisal, Vol. 6 Nos 3/4, pp. 261-275.

Olanrewaju, A.A. and Lee, A.H.J. (2022), "Investigation of the poor-quality practices on building construction sites in Malaysia”, Organization, Technology and Management in Construction: An International Journal, in press.

Olanrewaju, A.L. and Idrus, A. (2020), "What is determining affordable housing shortages in the Greater Kuala Lumpur, Malaysia?”, Property Management, Vol. 38 No. 1, pp. 52-81.

Oyewobi, L.O. and Ogunsemi, D.R. (2010), "Factors influencing rework occurrence in construction: a study of selected building projects in Nigeria”, Journal of Building Performance, Vol. 1 No. 1, pp. 1-20.

Palaneeswaran, E. (2006), "Reducing rework to enhance project performance levels", Proceedings of the One-Day Seminar on "Recent Developments in Project Management in Hong Kong", 12 May, pp. 5.1-5.10.

Plebankiewicz, E. and Malara, J. (2020), "Analysis of defects in residential buildings reported during the warranty period”, Applied Sciences, Vol. 10 No. 17, p. 6123.

Rahimi, Y., Tavakkoli-Moghaddam, R., Shojaie, S. and Cheraghi, I. (2017), "Design of an innovative construction model for supply chain management by measuring agility and cost of quality: an empirical study", Scientia Iranica, Vol. 24 No. 5, pp. 2515-2526.

Rosenfeld, Y. (2009), "Cost of quality versus cost of non-quality in construction: the crucial balance", Construction Management and Economics, Vol. 27 No. 2, pp. 107-117. 
FEBE

2,2

94

Shohet, M.I. and Ciabocco, L. (2016), "On-site mobile application for command, control and communication of safety and quality”, Creative Construction Conference.

Simpeh, E.K., Ndihokubwayo, R., Love, P.E. and Thwala, W.D. (2015), “A rework probability model: a quantitative assessment of rework occurrence in construction projects", International Journal of Construction Management, Vol. 15 No. 2, pp. 109-116.

Tang, S.L., Aoieong, R.T. and Ahmed, S.M. (2004), "The use of Process Cost Model (PCM) for measuring quality costs of construction projects: model testing”, Construction Management and Economics, Vol. 22 No. 3, pp. 263-275.

The Star Online (2017), "Portion of building under construction collapses, three injured", available at: https://www.thestar.com.my/news/nation/2017/05/13/portion-of-buildingunder-constructioncollapses-three-injured/ (accessed 13 December 2019).

The Star Online (2019a), “Three construction workers escape death after building collapses”, available at: https://www.thestar.com.my/news/nation/2019/05/23/three- construction-workers-escapedeath-after-building-collapses\#iYWZ6GDzJBwJdyxU.99 (accessed 13 December 2019).

The Star Online (2019b), "Due to safety measures, no injuries reported in Sri Petaling condo mishap, say developers", available at: https://www.thestar.com.my/news/nation/2019/07/04/ due-tosafety-measures-no-injuries-reported-in-sri-petaling-condo-mishap-say-developers\#XbLvDKq M3EGEeAO4.99 (accessed13 December 2019).

United Nations Economic Commission for Europe (2021), "Share of construction in GDP”, available at: https://w3.unece.org/PXWeb/en/CountryRanking?IndicatorCode=8 (accessed 12 February 2021).

Yap, J.B.H., Low, P.L. and Wang, C. (2017), "Rework in Malaysian building construction: impacts, causes and potential solutions", Journal of Engineering, Design and Technology, Vol. 15 No. 5, pp. 591-618.

Yatim, M.H. and Zakaria, S.A.A. (2008), "The application of quality control in construction industry a case study on customer satisfaction in housing projects", in Abdul Rashid, K. (Ed.), Research in the Malaysian Construction Industry and Built Environment: Past, Present and Future, International Islamic University Malaysia, Kuala Lumpur, 18-19 June 2008, pp. 165-179.

Zalejska-Jonsson, A. and Hungria Gunnelin, R. (2019), "Defects in newly constructed residential buildings: owners' perspective”, International Journal of Building Pathology and Adaptation, Vol. 37 No. 2, pp. 163-185.

\section{Further reading}

Wolstenholme, A., Austin, S.A., Bairstow, M., Blumenthal, A., Lorimer, J., McGuckin, S. and Guthrie, W. (2009), "Never waste a good crisis: a review of progress since rethinking construction and thoughts for our future", Constructing Excellence, October, available at: www. constructingexcellence.org.uk (accessed 11 December 2019).

\section{Corresponding author}

AbdulLateef Olanrewaju can be contacted at: olanrewaju20002000@gmail.com

For instructions on how to order reprints of this article, please visit our website:

www.emeraldgrouppublishing.com/licensing/reprints.htm

Or contact us for further details: permissions@emeraldinsight.com 